\title{
The Pathogenicity of Shewanella algae and Ability to Tolerate a Wide Range of Temperatures and Salinities
}

\author{
Shu-Ying Tseng, ${ }^{1}$ Po-Yu Liu, ${ }^{2}$ Yi-Hsuan Lee, ${ }^{1}$ Zong-Yen Wu ${ }^{D},{ }^{1}$ Chiu-Chen Huang, \\ Ching-Chang Cheng, ${ }^{4}$ and Kwong-Chung Tung $\mathbb{1}^{1}$ \\ ${ }^{1}$ Department of Veterinary Medicine, College of Veterinary Medicine, National Chung-Hsing University, Taichung, Taiwan
${ }^{2}$ Division of Infectious Diseases, Department of Internal Medicine, Taichung Veterans General Hospital, Taichung, Taiwan
${ }^{3}$ Sing-Wang of Animal Hospital, Taichung, Taiwan
${ }^{4}$ Laboratory Animal Service Center, Office of Research and Development, China Medical University, Taichung 40402, Taiwan
}

Correspondence should be addressed to Kwong-Chung Tung; kctung98@gmail.com

Received 22 June 2018; Revised 31 July 2018; Accepted 13 August 2018; Published 27 September 2018

Academic Editor: Paola Di Carlo

Copyright (c) 2018 Shu-Ying Tseng et al. This is an open access article distributed under the Creative Commons Attribution License, which permits unrestricted use, distribution, and reproduction in any medium, provided the original work is properly cited.

\begin{abstract}
Shewanella algae is a rod-shaped Gram-negative marine bacterium frequently found in nonhuman sources such as aquatic ecosystems and has been shown to be the pathogenic agent in various clinical cases due to the ingestion of raw seafood. The results of this study showed that $S$. algae was present in approximately one in four samples, including water and shellfish samples. Positive reactions (API systems) in S. algae strains were seen for gelatinase (gelatin); however, negative reactions were found for indole production (tryptophan). S. algae is adapted to a wide range of temperatures $\left(4^{\circ} \mathrm{C}, 25^{\circ} \mathrm{C}, 37^{\circ} \mathrm{C}\right.$, and $\left.42^{\circ} \mathrm{C}\right)$ and salinity. Temperature is a key parameter in the pathogenicity of $S$. algae as it appears to induce hemolysis at $25^{\circ} \mathrm{C}$ and $37^{\circ} \mathrm{C}$. S. algae exhibits pathogenic characteristics at widely varying temperatures, which suggests that it may have the ability to adapt to climate change.
\end{abstract}

\section{Introduction}

Recent studies indicate that climate change is driving ocean systems to recent increases in sea temperatures, with an associated risk of bacterial pathogens activity [1]. Shewanella algae has been identified as a new bacterial species, Shewanella spp., from clinical samples [2]. It is a rare human pathogen and symptoms of infection are often misidentified as Vibrio spp. [3]. It can be isolated from a wide range of environments, including fresh water, estuary, and the deep sea [4]. Risk factors associated with $S$. algae infections include chronic skin ulcer, chronic liver disease, and immune system disorders [5-7]. It appears to be more virulent in comparison with other Shewanella species [8-10].

Reports of infection with S. algae species in human cases are increasing, especially during the summer months and in tropical areas, such as India, China, and Taiwan [11-14]. In general, S. algae can be considered an opportunistic pathogen in humans exposed to a marine environment when it infects people via an existing soft tissue ulcer [15-22]. They have also been implicated in ear infection [23], eye infection, infective arthritis, osteomyelitis, bacteremia [24], infective endocarditis, and peritonitis in clinics [7]. Furthermore, S. algae infection tends to be associated with the ingestion of raw seafood, especially in individuals with hepatobiliary disease $[3,6,13,25]$. This is a particular concern in some Asian regions in which there is a high demand for a wide variety of raw seafood. However, to date, there are few detailed data on S. algae with respect to its biochemical profiles and sources of infection in aquaculture.

In light of these questions, we conducted a study to analyze aquaculture and diverse water sources in order to determine the distribution of $S$. algae. Furthermore, we determined the profiles of samples obtained from diverse 
ranges of salinity and temperature. These results may serve as the basis of further study and could shed light on the ability of this pathogen to adapt to climate change.

\section{Materials and Methods}

2.1. Sample Collection and Preparation. Aquaculture and water samples were randomly collected from commercial oyster seedbeds along the west coast of Taiwan, fish markets, fishing ports, commercial abalone farms on the east coast, and some estuaries. The aquaculture samples were placed in sterile plastic bags, and water samples were collected in transportation tubes.

All samples were transported in refrigerated containers immediately after being collected. A total of 109 samples (water isolates $(n=25)$ and aquaculture isolates $(n=84)$ collected from 2012 to 2013 were investigated in this study (Figure 1).

Each isolate from the digestive glands of oysters, abalone, clams, and water samples were prepared on marine broth 2216 (MB; BD) as tenfold dilutions [26].

Secondary enrichment incubation was applied for 48 hours, and then $2 \mu \mathrm{L}$ of culture media was taken by loop and directly placed on the surface of marine agar 2216 (MA; BD). Colonies on marine agar were $2.0-2.5 \mathrm{~mm}$ in diameter, circular, convex with entire margins, and smooth after 2 days' incubation at $30^{\circ} \mathrm{C}$. Orange-yellow or pink colonies on marine agar (BD) were identified as Gram-negative by Gram staining.

2.2. Biochemical and Nucleotide Sequence Analyses. The isolates were identified to species level by $16 \mathrm{~S}$ rDNA sequence nucleotide sequence analyses. Each of the isolates identified by PCR analyses tested positive for $16 \mathrm{~S}$ rDNA. Biochemical testing for phenotype was performed using an API20 NE (bioMérieux). All tests were performed according to the manufacturers' instructions. PCR-mediated amplification of the 16S rDNA was performed for confirmation of species identity. For nucleotide sequence analyses, genomic DNA was purified from overnight cultures of the isolates after growth on marine agar. The nucleotide was purified by using a QIAquick PCR purification kit (Qiagen). The extracted DNA was stored at $-20^{\circ} \mathrm{C}$ until processing.

The remaining PCR solution was prepared for sequencing to confirm species identity. A fragment of the $16 \mathrm{~S}$ rDNA gene was PCR-amplified from each genomic preparation using forward primer 27F: $5^{\prime}$-AGAGTTTGATCCTGGCTCAG- $3^{\prime}$ and 1492R: 5'-TACGGCTACCTTGTTACGACTT-3'. Reaction mixtures were incubated in an Eppendorf of PerkinElmerk GeneAmp 9600 PCR system. The reaction mix was put through the following temperatures with an initial denaturation for $1 \mathrm{~min}$ at $94^{\circ} \mathrm{C}, 1 \mathrm{~min}$ at $55^{\circ} \mathrm{C}$, and $5 \mathrm{~min}$ at $72^{\circ} \mathrm{C}$, for 30 cycles. The PCR products were thereafter cooled at $4^{\circ} \mathrm{C}$. Sequences of these amplicons were completed by ABI 3730xl DNA Analyzer (Applied Biosystems). Reference sequences utilized in phylogenetic analysis were retrieved from NCBI's GenBank database. The $16 \mathrm{~S}$ rDNA sequence data were compared with all currently available sequences of organisms belonging to the genus Shewanella.

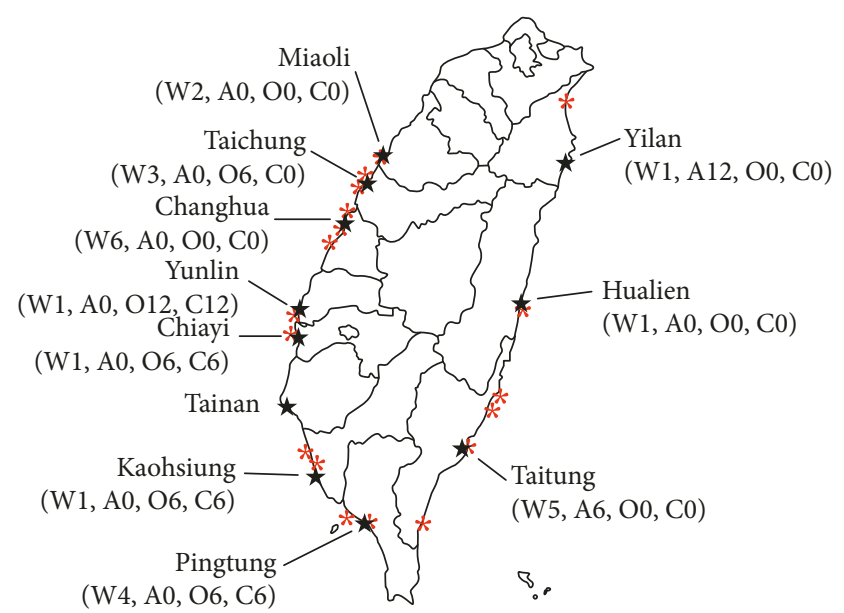

FIgURE 1: Location of sampling points of the aquaculture samples ( ; A: Abalone; C: Clams; O: Oyster) and water samples (*; W: water samples) in this study.

Phenotypic characteristic assays included growth conditions (temperature and salinity tolerance). Assessment of biochemical features included measurement of oxidase, hydrogen sulfide, and indole production. Carbohydrate and fatty acids utilization, as well as hemolytic activity, was analyzed.

2.3. Phenotypic Characteristic Assays. Include growth conditions (temperature and salinity tolerance) and biochemical features (oxidase, hydrogen sulfide, and indole production; carbohydrate and fatty acids utilization; and hemolytic activity).

2.4. Cellular Characterization. The isolates were then grown in an overnight marine broth and the turbidity diluted to match a 0.5 MacFarland standard prior to inoculation at different temperatures ( $24 \mathrm{hrs} \sim 7$ days). All strains were tested for the ability to grow on $\mathrm{MB}$ and then placed into four separate incubators at $4^{\circ} \mathrm{C}, 25^{\circ} \mathrm{C}, 37^{\circ} \mathrm{C}$, and $42^{\circ} \mathrm{C}$ for culturing (7 days). The growth of the isolates was routinely assessed indirectly by measuring the turbidity $\left(\mathrm{OD}_{600 \mathrm{~nm}}\right)$ using a UV-visible spectrophotometer (Tecan infinite 200, Switzerland). Growth was determined as an absorbance reading at or above 0.1 .

2.5. Hemolysis Assay. To investigate the presence of potential virulence factors, we observed the hemolytic activity of $S$. algae on plates of $5 \%$ sheep blood agar (Commercialized Blood Agar Plate, Creative Co., Ltd., Taiwan) after incubation at two different temperatures $\left(25^{\circ} \mathrm{C}\right.$ and $\left.37^{\circ} \mathrm{C}\right)$ and for two different times ( $24 \mathrm{hrs}$ and $72 \mathrm{hrs}$ ).

2.6. Salinity Tolerance Assay. The salinity tolerance screening assay of the selected bacterial strains was carried out using tryptic soy broth (TSB, Difco) medium with $0-10 \%$ 
$(\mathrm{w} / \mathrm{v})$ concentration of $\mathrm{NaCl}$. The flasks were inoculated with bacterial culture and incubated at $30^{\circ} \mathrm{C}$ on a rotator shaker (180 rpm) for $48 \mathrm{hrs}$. The bacterial growth assessment was carried out by measuring the turbidity $\left(\mathrm{OD}_{600 \mathrm{~nm}}\right)$ using a fluorescence spectrophotometer (Tecan infinite 200, Switzerland). The experiments were conducted in triplicate and the average values were recorded. The bacterial isolates were grown at $30^{\circ} \mathrm{C}$ for 7 days.

2.7. Statistical Analysis. Data were entered into Microsoft Excel 2017 (Microsoft Corporation, Redmond, USA) and analyzed.

\section{Results}

3.1. Quantity of Bacteria in Collected Samples. A total of 109 samples were collected. In total, $23 \%(19 / 84)$ of isolates from shellifishes and $28 \%(7 / 25)$ of water isolates were identified as Shewanella algae (Tables 1 and 2). We tested the significant differences in the isolation rates between water samples and shellfishes using Pearson's chi square with Yates' continuity correction. We found no significant difference between the two group ( $p=0.798$ and $R=0.022$ ). The phenomenon suggests potential extensive water contamination which warrants continuous surveillance.

The bivalve mussels were identified by the Department of Life Sciences, National Chung Hsing University. The mussels were confirmed to be related to Crassostrea angulata, Meretrix lusoria, Perna viridis, Geloina erosa, and Haliotis diversicolor. Among these, the isolation rates of Shewanella algae were 2/18 in abalone (Haliotis diversicolor), $11 / 36$ in oyster (Crassostrea angulata), and 6/30 in clams including Meretrix lusoria, Perna viridis, and Geloina erosa (Table 1). In addition, the locations with the greatest prevalence of Shewanella algae in water samples were commercial aquaculture farms on the west coast, with an isolation rate of $37.5 \%(3 / 8)$, followed by fish markets in fishing ports on the east coast, with a rate of $26.7 \%(4 / 15)$ (Table 2).

3.2. Characterization of Shewanella Strains. S. algae isolates were cultured at four different temperatures to establish reference data for future research on possible adaptation to global warming. The results showed $S$. algae isolates grew at three temperatures within the linear range $(25,37$, and $42^{\circ} \mathrm{C}$ ), but grew poorly at $4^{\circ} \mathrm{C}$ (Table 3 ). The growth curves of S. algae under different temperature are shown in Figure 2.

The biochemical profiles showed that all of the strains were unable to utilize some carbohydrates, but produced hydrogen sulfide $\left(\mathrm{H}_{2} \mathrm{~S}\right)$. Positive reactions in $\mathrm{S}$. algae strains were seen for $\mathrm{H}_{2} \mathrm{~S}$ (from sodium thiosulfate) and cytochrome oxidase (oxidase test) and gelatinase (gelatin); however, negative results were found for indole production (tryptophan) and carbohydrates utilization, including arabinose, mannose, mannitol, adipic acid, and phenylacetic acid (Table 3).

Some $S$. algae isolates produced urease, which were related to positive urea reaction. Furthermore, most S. algae strains shared the ability to react with $\mathrm{N}$-acetyl-glucosamine (NAG) as membrane substrates and reduction of nitrate to nitrite (potassium nitrate), and few S. algae isolates were able to assimilate maltose. Moreover, the majority of $S$. algae isolates assimilated capric acid and malic acid.

3.3. Effect of Salinity and Hemolysis In Vitro. The cultures were incubated at $30^{\circ} \mathrm{C}$ and all of them grew in the presence of a wide range of $\mathrm{NaCl}$ concentrations from $0,2 \%, 6 \%$, and $10 \%(\mathrm{w} / \mathrm{v})$ (Table 3$)$. Comparing the growth effects in different conditions, the isolates from aquaculture and water samples were favored by $0 \%, 2 \%$, and $6 \%$ salinity. However, no bacterial growth was found at $10 \% \mathrm{NaCl}$.

Hemolysis occurred in sheep blood agar after incubation at two different temperatures $\left(25^{\circ} \mathrm{C}\right.$ and $37^{\circ} \mathrm{C}$ ) (Table 3). One hundred percent hemolysis was found in S. algae from both aquaculture and water isolates at $37^{\circ} \mathrm{C}$ (after 72 hours). Compared with the $25^{\circ} \mathrm{C}$ group, only $50 \%$ hemolysis occurred after 72 hours.

\section{Discussion}

In this study, we investigated the prevalence of $S$. algae in a variety of environments around Taiwan. We collected 109 samples and identified S. algae in 23\% (19/84) of isolates from shellfishes and in $28 \%(7 / 25)$ of water isolates (Tables 1 and 2).

S. algae can be found in samples from coastal areas, aquaculture farms, and aquaculture products [27]. S. algae is frequently found in the marine environment and is widely distributed in nature. Reports of infections with this opportunistic pathogen in humans are rare, although they are on the rise. In many clinical reports of hepatobiliary disease involving $S$. algae infection, there was a history of raw seafood ingestion $[3,25]$. However, reports of $S$. algae infection in aquatic animals are rare. In view of this, we searched for articles on relevant cases in the ScienceDirect, PubMed, and Google Scholar databases using the following terms: "Aquaculture disease or Aquaculture products or Environment" in conjunction with "Shewanella algae or Shewanella alga." The collected studies included research articles and case reports, as well as retrospective and series studies. Table 4 shows a list of results for $S$. algae infections in aquaculture animals from 1999 to 2017 in different countries $[15,16,28-40]$. The results showed that $S$. algae is endemic in Asia. This finding is consistent with a number of studies conducted in areas with warm climates, largely in Asia [9, 41, 42]. A literature review of the period 1999 to 2017 showed that over $64 \%(9 / 14)$ of infection cases in aquatic animals were in Asia, including China, Japan, Malaysia, and Iran, as shown in Table 4. In addition, sea water was the predominant source of contamination and some cases were without disease symptoms.

In many reports of human infection with $S$. algae, the patient had a previous history of hepatobiliary disease or hemochromatosis and had recently consumed raw seafood $[25,28]$. It is well understood that patients with hereditary hemochromatosis or hepatobiliary disease are prone to iron overload $[43,44]$. S. algae could be tolerant to bile salts and 
TABLE 1: Incidence of Shewanella algae in aquaculture samples.

\begin{tabular}{|c|c|c|c|c|}
\hline Location & Sources of sample & Genus species & Total no. of samples & No. yielding Shewanella algae \\
\hline TaiTung & Abalone (cultured) & Haliotis diversicolor & 6 & 2 \\
\hline Yilan & Abalone (cultured) & Haliotis diversicolor & 12 & 0 \\
\hline YunLin & Oyster (cultured) & Crassostrea angulate & 12 & 1 \\
\hline ChiaYi & Oyster (cultured) & Crassostrea angulate & 6 & 2 \\
\hline KaoHsiung & Oyster (cultured) & Crassostrea angulate & 6 & 2 \\
\hline Taichung & Oyster (Fish market) & Crassostrea angulate & 6 & 2 \\
\hline PingTung & Oyster (cultured) & Crassostrea angulate & 6 & 4 \\
\hline YunLin & Clam (cultured) & Geloina erosa & 12 & 1 \\
\hline KaoHsiung & Clam (cultured) & Meretrix lusoria & 6 & 3 \\
\hline ChiaYi & Clam (cultured) & Meretrix lusoria & 6 & 0 \\
\hline PingTung & Clam (cultured) & Perna viridis & 6 & 2 \\
\hline Total number & & & 84 & 19 \\
\hline Isolation rate (\%) & & & & 23 \\
\hline
\end{tabular}

TABLE 2: Occurrence of Shewanella algae in different water-sampling sites.

\begin{tabular}{|c|c|c|c|}
\hline Location & Sources of sample & No. of cultured & No. yielding Shewanella algae \\
\hline Miaoli County (Houlong Township) & Mariculture & 2 & 1 \\
\hline Changhua County (Yuanlin Township) & Sea gate & 3 & 1 \\
\hline Changhua County (Fishing port) & Sea water & 3 & 0 \\
\hline Taichung City (Dali Dist.) & Fresh water & 1 & 0 \\
\hline Taichung City (Wuqi Dist.) & Sea water & 2 & 0 \\
\hline Yunlin County (Kouhu Township) & Mariculture & 1 & 0 \\
\hline Chiayi County (Budai Township) & Sea water & 1 & 0 \\
\hline Kaohsiung City (Ziguan Dist.) & Sea water & 1 & 0 \\
\hline Pingtung County (Fangliao Township) & Mariculture & 4 & 2 \\
\hline Taitung County & Sea water & 4 & 2 \\
\hline Taitung County (Donghe Township) & Fresh water & 1 & 0 \\
\hline Hualien County (Fengbin Township) & Sea water & 1 & 1 \\
\hline Yilan County (Toucheng Township) & Mariculture & 1 & 0 \\
\hline Total numbers & & 25 & 7 \\
\hline Isolation rate $(\%)$ & & & 28 \\
\hline
\end{tabular}

may produce tetrodotoxin [42], exoenzymes, or siderophores [8], which are considered virulence factors. Furthermore, iron $(\mathrm{Fe})$ serves as a terminal electron acceptor when Shewanella spp. are exposed to anoxic conditions $[45,46]$.

Our results showed $S$. algae strains are capable of growing in the presence of $0 \sim 6 \% \mathrm{NaCl}$. Shewanella spp. are commonly found in marine environments and are believed to be halophilic bacteria $[47,48]$. The traditional methods of processing seafood often take advantage of the preservative properties of salt, which permit long-term storage. The high salinity in the seafood product may influence the osmotic pressure and physiological properties of any bacteria that may be present. High salinity can result in the loss of microbial activity and cell plasmolysis. However, moderately salt-tolerant bacteria can resist or reduce the damaging effects of salt concentrations of up to $5-20 \%$ salinity [49]. Therefore, these salt-tolerant bacteria are potential foodborne pathogens. In our results, growth of $S$. algae was observed in a wide range of salinities (Table 3). Surprisingly, $S$. algae was also found in fresh water and nonmarine environments, and thus did not appear to require $\mathrm{Na}^{+}$, as shown in Table 3.
Furthermore, the seasonal growth and infection rate of $S$. algae peak during the summer. Based on the growth curves in our study, S. algae adapt to a wide range of temperatures, with optimal growth temperatures ranging at room temperature; under experimental conditions, the optimal temperatures for bacterial growth were $25^{\circ} \mathrm{C}$ and $37^{\circ} \mathrm{C}$ (Table 3 ). Comparing the two isolates of the curves based on optical density, the curves of growth rate versus temperature are in direct proportion as drawn in Figure 2. This probably explains why reports of $S$. algae infection are more common in warm water areas or tropical regions during the summer than in cold-water environments [8]. Prior study revealed that $S$. algae grows under the condition of temperature $26-34^{\circ} \mathrm{C}$, pH 5-9 [40]. The data provide further support of the capacity of survival of $S$. algae under ocean acidification caused by global warming.

Earlier research has suggested that hemolysis may be used as a marker to predict potentially virulent strains of $S$. algae [3]. We previously reported that a substantial number of $S$. algae strains were capable of growing on sheep blood agar. S. algae strains from all isolates exhibited hemolysis on sheep blood agar. In Table 3, it can be seen hemolytic activity on sheep blood agar was high $(90 \%$ to $100 \%)$ at $37^{\circ} \mathrm{C}$. In 
TABLE 3: Phenotypic characteristics of Shewanella algae isolates.

\begin{tabular}{|c|c|c|}
\hline \multirow{2}{*}{ Reaction } & \multicolumn{2}{|c|}{ Values are positive percentages } \\
\hline & Aquaculture isolates $(n=19)(\%)$ & Water isolates $(n=7)(\%)$ \\
\hline \multicolumn{3}{|l|}{ Growth at } \\
\hline $4^{\circ} \mathrm{C}$ on $\mathrm{MB}$ & 0 & 14 \\
\hline $25^{\circ} \mathrm{C}$ on $\mathrm{MB}$ & 100 & 100 \\
\hline $37^{\circ} \mathrm{C}$ on $\mathrm{MB}$ & 100 & 100 \\
\hline $42^{\circ} \mathrm{C}$ on $\mathrm{MB}$ & 74 & 100 \\
\hline $30^{\circ} \mathrm{C}$ in $\mathrm{LB}$ with $0 \% \mathrm{NaCl}$ & 100 & 100 \\
\hline $30^{\circ} \mathrm{C}$ in $\mathrm{LB}$ with $2 \% \mathrm{NaCl}$ & 100 & 100 \\
\hline $30^{\circ} \mathrm{C}$ in $\mathrm{LB}$ with $6 \% \mathrm{NaCl}$ & 100 & 100 \\
\hline $30^{\circ} \mathrm{C}$ in $\mathrm{LB}$ with $10 \% \mathrm{NaCl}$ & 0 & 0 \\
\hline \multicolumn{3}{|l|}{ Hemolysis of blood agar plate at } \\
\hline $37^{\circ} \mathrm{C}(24 \mathrm{hrs})$ & 89 & 100 \\
\hline $25^{\circ} \mathrm{C}(24 \mathrm{hrs})$ & 0 & 0 \\
\hline $37^{\circ} \mathrm{C}(72 \mathrm{hrs})$ & 100 & 100 \\
\hline $25^{\circ} \mathrm{C}(72 \mathrm{hrs})$ & 53 & 57 \\
\hline \multicolumn{3}{|l|}{ Reactions/enzymes (API20NE) } \\
\hline Reduction of nitrates to nitrites & 100 & 100 \\
\hline Indole production & 0 & 0 \\
\hline Glucose fermentation & 0 & 0 \\
\hline Arginine dihydrolase & 5 & 0 \\
\hline Urease & 32 & 29 \\
\hline$\beta$-Glucosidase & 53 & 43 \\
\hline Gelatinase & 95 & 100 \\
\hline$\beta$-Galactosidase & 11 & 0 \\
\hline \multicolumn{3}{|l|}{ Assimilation (API20NE) } \\
\hline Glucose & 0 & 14 \\
\hline Arabinose & 0 & 0 \\
\hline Mannose & 0 & 0 \\
\hline Mannitol & 0 & 0 \\
\hline$N$-Acetyl-glucosamine & 95 & 100 \\
\hline Maltose & 16 & 14 \\
\hline Potassium gluconate & 0 & 14 \\
\hline Capric acid & 79 & 71 \\
\hline Adipic acid & 0 & 0 \\
\hline Malic acid & 100 & 86 \\
\hline Trisodium citrate & 11 & 29 \\
\hline Phenylacetic acid & 0 & 0 \\
\hline \multicolumn{3}{|l|}{ Others } \\
\hline Oxidase & 100 & 100 \\
\hline $\mathrm{H}_{2} \mathrm{~S}$-production (TSIA) & 100 & 100 \\
\hline
\end{tabular}

contrast, there was no obvious hemolysis on the first day of incubation at $25^{\circ} \mathrm{C}$; however, it was clearly evident on the second day. This finding implies that Shewanella species exert various forms of hemolysis. Our results are also consistent with epidemiologic studies in Denmark [28] and Taiwan [25], which showed the infection rates of $S$. algae were correlated with temperature fluctuation. In general, most S. alga strains exhibited hemolysis after prolonged incubation ( 48 to $72 \mathrm{~h}$ ) and the area of hemolysis was clear.

The major characteristics in all $S$. algae isolates in this study include the ability to exert a strong hemolytic effect: an inability to utilize carbohydrates, although a few isolates were able to use maltose from some water samples. Other studies previously found that a few Shewanella species could utilize L-arabinose and glucose $[9,50]$; however, we were not able to confirm these results.
S. algae utilizes few carbohydrates as the sole carbon source according to the results of this study. In principle, bacteria are quite diverse in terms of nutrient utilization and metabolic requirements in a specific environment, owing to their biosynthetic capabilities. Previous biochemical characterization studies have suggested that while some Shewanella species are able to metabolize different sugars for growth, they might be limited to biosynthetic purposes such as cell wall synthesis or as a storage molecule, rather than as a carbon source $[51,52]$. This could explain the apparent inconsistencies among several experimental observations. In our results, only $14 \%$ of $S$. algae from diverse water sources and $16 \%$ of aquaculture isolates utilized maltose (Table 3). From these, we may infer $S$. algae adapt to environmental changes via different biosynthetic pathways. Shewanella spp. possess a number of mechanisms to assimilate carbohydrates 


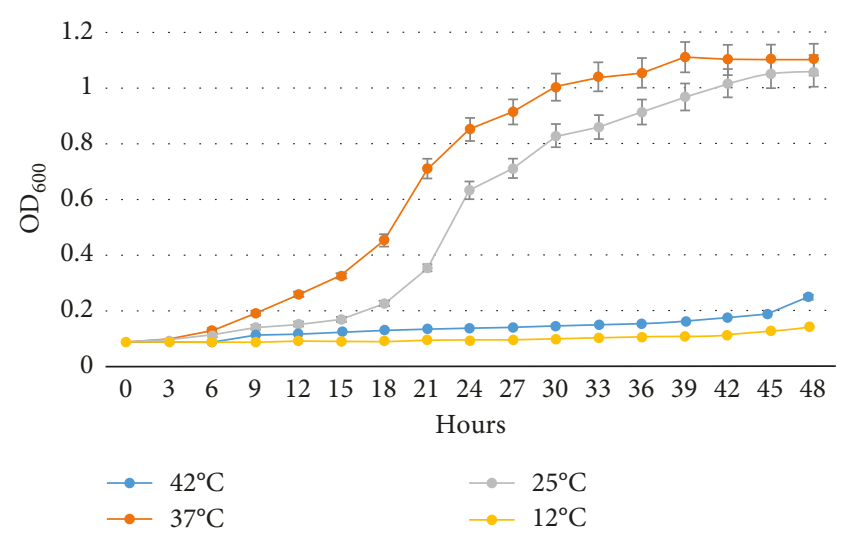

(a)

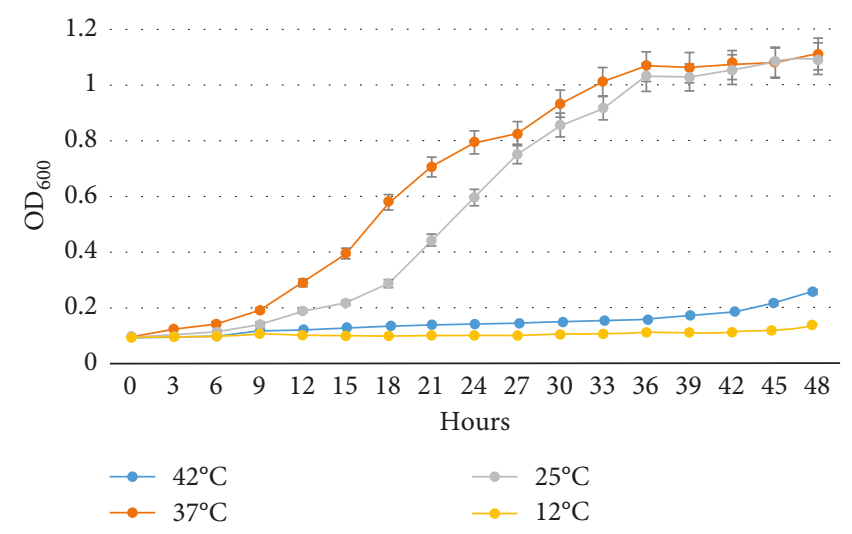

(b)

FIgURE 2: Growth curve of Shewanella algae isolates. (a) Aquaculture-origin, laboratory ID: O12. (b) Water-origin, laboratory ID: E-W1. Shewanella algae isolates were cultivated in LB broth at $12,25,37$, and $42^{\circ} \mathrm{C}$ with shaking at $200 \mathrm{rpm}$. The optical density $\left(\mathrm{OD}_{600}\right)$ was measured every 3 hours from zero point until 48 hours.

TABLE 4: Distribution of Shewanella algae in environment samples and aquaculture animals (1999-2017).

\begin{tabular}{|c|c|c|c|c|c|}
\hline Year & Region & Sampling location & Host & Disease symptoms & References \\
\hline 1999 & Denmark & Sea water & Environment samples & No & Gram et al., [28] \\
\hline 2000 & Denmark & Sea water & Environment samples & No & Vogel et al., [15] \\
\hline 2002 & China & Sea water & Scinenops ocellata & Ulcer disease & Chang et al., [16] \\
\hline 2006 & China & Pond water & Abalone & Whitening, shrunken muscles & Cai et al., [29] \\
\hline 2008 & USA & Sea water & Shellfish & Nonavailable & Richards et al., [30] \\
\hline 2009 & Japan & Sea water & Sea cucumber & Nonavailable & Beleneva et al., [31] \\
\hline 2010 & Malaysia & Tank water & Shrimp & Healthy post larvae & Zadeh et al., [32] \\
\hline 2010 & Japan & Tank water & Pufferfish & Healthy fish & Sugita et al., [33] \\
\hline 2011 & USA & Sea water & Sediments & No & Cummings et al., [34] \\
\hline 2012 & China & Sea water & Environment samples & No & Zhao and Dang, [35] \\
\hline 2013 & China & Sea water & Marine culture & No & Liu et al., $[25,36,37]$ \\
\hline 2013 & China & Sea water & Deep-sea sediments & No & Jiang et al., [36] \\
\hline 2013 & Portuguese & Sea water & Deep sea & No & Martins et al., [38] \\
\hline 2015 & Iran & Sea water & Mussels/sediment & No & Bayat et al., [39] \\
\hline 2017 & China & Sea water & Fish & Noticeable histological lesions & Z. Han et al., [40] \\
\hline
\end{tabular}

from the environment. It has been proposed that Shewanella oneidensis MR-1 uses the formaldehyde produced from pyruvate during growth under anaerobic or oxygen-limited conditions [53].

In addition, the results of indole production were all negative for $S$. algae isolates. Indole can act as an extracellular signal to regulate biofilm-promoting factors and the expression of adhesion molecules [54]. Bacteria which give negative results for the indole test include some Aeromonas species and Vibrio spp. [55]. Recent studies showing that non-indole-producing bacteria generate various oxygenases which may degrade indole or interfere with indole signaling $[56,57]$. Many oxygenase and reductase reactions may be involved in metal ion facilitation in bacteria [58]. The ability of $S$. oneidensis to reduce oxidized metals or nitrate effectively has been identified as an important intrinsic activity of Shewanella species [59-62]. These results all indicate that $S$. algae is capable of adapting to environmental changes.
Further studies are needed to clarify the role of regulating the intrinsic activity of S. algae.

There were several limitations in this study. First, continuous multisite surveillance is needed to demonstrate seasonal variation and long-term effect of global warming on S. algae population. Second, the lack of discrimination by the API systems for Shewanella bacteria is understandable since the isolates show diverse results in biochemical testing. It is necessary to improve identification schemes to identify pathogenic and nonpathogenic strains of $S$. algae in the natural environment.

In summary, our study identified the presence of S. algae in water and aquaculture products in Taiwan. We further identified hemolytic activity in all isolates, indicating that this species of bacteria possesses a pathogenic potential. We found high levels of $S$. algae isolates contained in diverse sources (oysters, abalone, clam, and water samples). The ability of Shewanella strains to tolerate a wide range of 
temperatures and salinities in experimental challenges may be due to the expression or repression of genes, but further research is needed to explore the potential underlying mechanisms involved. These results suggest that monitoring the levels of pathogenic species and strains should be continued in Taiwan and expanded to other tropical and subtropical zones in Asia.

\section{Data Availability}

The data used to support the findings of this study are currently under embargo while the research findings are published. Requests for data, 6 months after publication of this article, will be considered by the corresponding author.

\section{Conflicts of Interest}

The authors declare that they have no conflicts of interest.

\section{Authors' Contributions}

Shu-Ying Tseng wrote the manuscript. Zong-Yen $\mathrm{Wu}$ and Po-Yu Liu conducted the data analysis and contributed to the microbiological analysis. Yi-Hsuan Lee, Ching-Chang Cheng, and Chiu-Chen Huang collected samples from different areas. Chiu-Chen Huang repeated the growth curves of $S$. algae under different temperature. KwongChung Tung revised the manuscript. All authors contributed to data analysis, drafting, and critically revising the paper, read and approved the final manuscript, and agreed to be accountable for all aspects of the work.

\section{References}

[1] M. Bally and J. Garrabou, "Thermodependent bacterial pathogens and mass mortalities in temperate benthic communities: a new case of emerging disease linked to climate change," Global Change Biology, vol. 13, no. 10, pp. 20782088, 2007.

[2] H. Nozue, T. Hayashi, Y. Hashimoto et al., "Isolation and characterization of Shewanella alga from human clinical specimens and emendation of the description of $S$. alga Simidu et al., 1990, 335," International Journal of Systematic Bacteriology, vol. 42, no. 4, pp. 628-634, 1992.

[3] D. S. Myung, Y.-S. Jung, S.-J. Kang et al., "Primary Shewanella algae bacteremia mimicking Vibrio septicemia," Journal of Korean Medical Science, vol. 24, no. 6, pp. 1192-1194, 2009.

[4] X. Fu, D. Wang, X. Yin, P. Du, and B. Kan, "Time course transcriptome changes in Shewanella algae in response to salt stress," PLoS One, vol. 9, no. 5, Article ID e96001, 2014.

[5] H. Domínguez, B. F. Vogel, L. Gram, S. Hoffmann, and S. Schaebel, "Shewanella alga bacteremia in two patients with lower leg ulcers," Clinical Infectious Diseases, vol. 22, no. 6, pp. 1036-1039, 1996.

[6] T. Otsuka, T. Noda, A. Noguchi, H. Nakamura, K. Ibaraki, and K. Yamaoka, "Shewanella infection in decompensated liver disease: a septic case," Journal of Gastroenterology, vol. 42, no. 1, pp. 87-90, 2007.

[7] J. Srinivas, M. Pillai, V. Vinod, and R. K. Dinesh, "Skin and soft tissue infections due to Shewanella algae: an emerging pathogen," Journal of Clinical and Diagnostic Research, vol. 9, no. 2, pp. DC16-DC20, 2015.
[8] S. Khashe and J. M. Janda, "Biochemical and pathogenic properties of Shewanella alga and Shewanella putrefaciens," Journal of Clinical Microbiology, vol. 36, no. 3, pp. 783-787, 1998.

[9] H. M. Holt, B. Gahrn-Hansen, and B. Bruun, "Shewanella algae and Shewanella putrefaciens: clinical and microbiological characteristics," Clinical Microbiology and Infection, vol. 11, no. 5, pp. 347-352, 2005.

[10] J. M. Janda, "Shewanella: a marine pathogen as an emerging cause of human disease," Clinical Microbiology Newsletter, vol. 36, no. 4, pp. 25-29, 2014.

[11] M.-S. Tsai, H.-L. You, Y.-F. Tang, and J.-W. Liu, "Shewanella soft tissue infection: case report and literature review," International Journal of Infectious Diseases, vol. 12, no. 6, pp. e119-e124, 2008.

[12] P.-Y. Liu, Z. Y. Shi, C. F. Lin et al., "Shewanella infection of snake bites: a twelve-year retrospective study," Clinics, vol. 67, no. 5, pp. 431-435, 2012.

[13] B. K. Kim, S.-Y. Cho, B. Kang et al., "A case of spontaneous bacterial peritonitis with bacteremia caused by Shewanella algae," Infection \& Chemotherapy, vol. 46, no. 4, pp. 264-268, 2014.

[14] B. G. Sumathi, S. R. Kumarswamy, U. Amritam, and R. Arjunan, "Shewanella algae: first case report of the fast emerging marine pathogen from squamous cell carcinoma patient in India," South Asian Journal of Cancer, vol. 3, no. 3, pp. 188-189, 2014.

[15] B. F. Vogel, H. M. Holt, P. Gerner-Smidt, A. Bundvad, P. Søgaard, and L. Gram, "Homogeneity of danish environmental and clinical isolates of Shewanella algae," Applied and Environmental Microbiology, vol. 66, no. 1, pp. 443-448, 2000.

[16] C. Chang, H. Chaoqun, C. Xiaoyan, and Z. Luping, "Identification and characterization of Shewanella algae as a novel pathogen of ulcer disease of fish Scinenops ocellata," Oceanologia et Limnologia Sinica, vol. 34, no. 1, pp. 1-8, 2002.

[17] T. Wang, "Model of life expectancy of chronic hepatitis B carriers in an endemic region," Journal of Epidemiology, vol. 19, no. 6, pp. 311-318, 2009.

[18] K. K. Sharma and U. Kalawat, "Emerging infections: Shewanella-a series of five cases," Journal of Laboratory Physicians, vol. 2, no. 2, pp. 61-65, 2010.

[19] R. Nath, G. Choudhury, L. Saikia, and P. Das, "Isolation of Shewanella algae from rectal swabs of patients with bloody diarrhoea," Indian Journal of Medical Microbiology, vol. 29, no. 4, p. 428, 2011.

[20] S. Wait and D.-S. Chen, "Towards the eradication of hepatitis B in Taiwan," Kaohsiung Journal of Medical Sciences, vol. 28, no. 1, pp. 1-9, 2012.

[21] N. Wagner, L. Otto, M. Podda, Y. Schmitt, and D. Tappe, "Travel-related chronic hemorrhagic leg ulcer infection by Shewanella algae," Journal of Travel Medicine, vol. 20, no. 4, pp. 262-264, 2013.

[22] T.-W. Wu, H. H. Lin, and L.-Y. Wang, "Chronic hepatitis B infection in adolescents who received primary infantile vaccination," Hepatology, vol. 57, no. 1, pp. 37-45, 2013.

[23] H. M. Holt, P. Søgaard, and B. Gahrn-Hansen, "Ear infections with Shewanella alga: a bacteriologic, clinical and epidemiologic study of 67 cases," Clinical Microbiology and Infection, vol. 3, no. 3, pp. 329-333, 1997.

[24] M. Iwata, K. Tateda, T. Matsumoto, N. Furuya, S. Mizuiri, and K. Yamaguchi, "Primary Shewanella alga Septicemia in a Patient on Hemodialysis," Journal of Clinical Microbiology, vol. 37, no. 6, pp. 2104-2105, 1999. 
[25] P.-Y. Liu, C.-F. Lin, K.-C. Tung et al., "Clinical and microbiological features of Shewanella Bacteremia in patients with hepatobiliary disease," Internal Medicine, vol. 52, no. 4, pp. 431-438, 2013.

[26] A. H. Al-Harbi and M. Naim Uddin, "Seasonal variation in the intestinal bacterial flora of hybrid tilapia (Oreochromis niloticus $\times$ Oreochromis aureus) cultured in earthen ponds in Saudi Arabia," Aquaculture, vol. 229, no. 1-4, pp. 37-44, 2004.

[27] J. P. S. Cabral, "Water microbiology. Bacterial pathogens and water," International Journal of Environmental Research, vol. 7, no. 10, pp. 3657-3703, 2010.

[28] L. Gram, A. Bundvad, J. Melchiorsen, C. Johansen, and B. F. Vogel, "Occurrence of Shewanella algae in Danish coastal water and effects of water temperature and culture conditions on its survival," Applied and Environmental Microbiology, vol. 65, no. 9, pp. 3896-3900, 1999.

[29] J. Cai, H. Chen, K. D. Thompson, and C. Li, "Isolation and identification of Shewanella alga and its pathogenic effects on post-larvae of abalone Haliotis diversicolor supertexta," Journal of Fish Diseases, vol. 29, no. 8, pp. 505-508, 2006.

[30] G. P. Richards, M. A. Watson, E. J. Crane, I. G. Burt, and D. Bushek, "Shewanella and Photobacterium spp. in oysters and seawater from the Delaware Bay," Applied and Environmental Microbiology, vol. 74, no. 11, pp. 3323-3327, 2008.

[31] I. A. Beleneva, T. Y. Magarlamov, M. G. Eliseikina, and N. V. Zhukova, "Biochemical and pathogenic properties of the natural isolate of Shewanella algae from peter the great bay, Sea of Japan," Journal of Invertebrate Pathology, vol. 102, no. 3, pp. 250-255, 2009.

[32] S. S. Zadeh, C. R. Saad, A. Christianus et al., "Assessment of growth condition for a candidate probiotic, Shewanella algae, isolated from digestive system of a healthy juvenile Penaeus monodon," Aquaculture International, vol. 18, no. 6, pp. 1017-1026, 2010.

[33] H. Sugita, K. Sugiyama, and S. Itoi, "Culturable bacterial flora in the intestinal tract of Japanese Pufferfish Takifugu rubripes," Aquaculture Science, vol. 58, no. 3, pp. 437-438, 2010.

[34] D. E. Cummings, K. F. Archer, D. J. Arriola et al., "Broad dissemination of plasmid-mediated quinolone resistance genes in sediments of two urban coastal wetlands," Environmental Science \& Technology, vol. 45, no. 2, pp. 447-454, 2011.

[35] J. Zhao and H. Dang, "Coastal seawater bacteria harbor a large reservoir of plasmid-mediated quinolone resistance determinants in Jiaozhou Bay, China," Microbial Ecology, vol. 64, no. 1, pp. 187-199, 2012.

[36] W. Jiang, B. Xia, and Z. Liu, "A serine hydroxymethyltransferase from marine bacterium Shewanella algae: isolation, purification, characterization and l-serine production," Microbiological Research, vol. 168, no. 8, pp. 477-484, 2013.

[37] G. Liu, J. Zhou, X. Meng et al., "Decolorization of azo dyes by marine Shewanella strains under saline conditions," Applied Microbiology and Biotechnology, vol. 97, no. 9, pp. 4187-4197, 2013.

[38] A. Martins et al., "Photoprotective bioactivity present in a unique marine bacteria collection from Portuguese deep sea hydrothermal vents," Marine Drugs, vol. 11, no. 5, pp. 1506-1523, 2013.

[39] Z. Bayat, M. Hassanshahian, and M. A. Hesni, "Enrichment and isolation of crude oil degrading bacteria from some mussels collected from the Persian Gulf," Marine Pollution Bulletin, vol. 101, no. 1, pp. 85-91, 2015.

[40] Z. Han, J. Sun, A. Lv et al., "Isolation, identification and characterization of Shewanella algae from reared tongue sole,
Cynoglossus semilaevis Günther," Aquaculture, vol. 468, pp. 356-362, 2017.

[41] R. Finkelstein and I. Oren, "soft tissue infections caused by marine bacterial pathogens: epidemiology, diagnosis, and management," Current Infectious Disease Reports, vol. 13, no. 5, pp. 470-477, 2011.

[42] N. Vignier, R. Théodose, M. Barreau et al., "Human infection with Shewanella putrefaciens and S. algae: report of 16 cases in martinique and review of the literature," American Journal of Tropical Medicine and Hygiene, vol. 89, no. 1, pp. 151-156, 2013.

[43] L. Schamroth, W. Edelstein, W. M. Politzer, and N. Stevens, "Serum iron in the diagnosis of hepatobiliary disease," BMJ, vol. 1, no. 4973, pp. 960-963, 1956.

[44] A. Pietrangelo, "Hereditary hemochromatosis: a new look at an old disease," New England Journal of Medicine, vol. 350, no. 23, pp. 2383-2397, 2004.

[45] K. L. Straub, M. Benz, and B. Schink, "Iron metabolism in anoxic environments at near neutral $\mathrm{pH}$," FEMS Microbiology Ecology, vol. 34, no. 3, pp. 181-186, 2001.

[46] K. A. Weber, L. A. Achenbach, and J. D. Coates, "Microorganisms pumping iron: anaerobic microbial iron oxidation and reduction," Nature Reviews Microbiology, vol. 4, no. 10, pp. 752-764, 2006.

[47] J. J. DeFrank, W. T. Beaudry, T.-C. Cheng, S. P. Harvey, A. N. Stroup, and L. L. Szafraniec, "Screening of halophilic bacteria and Alteromonas species for organophosphorus hydrolyzing enzyme activity," Chemico-Biological Interactions, vol. 87, no. 1-3, pp. 141-148, 1993.

[48] L. Gram and H. H. Huss, "Microbiological spoilage of fish and fish products," International Journal of Food Microbiology, vol. 33, no. 1, pp. 121-137, 1996.

[49] H. Larsen, "Halophilic and halotolerant microorganisms-an overview and historical perspective," FEMS Microbiology Letters, vol. 39, no. 1-2, pp. 3-7, 1986.

[50] B. F. Vogel, K. Jørgensen, H. Christensen, J. E. Olsen, and L. Gram, "Differentiation of Shewanella putrefaciens and Shewanella alga on the basis of whole-cell protein profiles, ribotyping, phenotypic characterization, and 16S rRNA gene sequence analysis," Applied and Environmental Microbiology, vol. 63, no. 6, pp. 2189-2199, 1997.

[51] K. Venkateswaran, D. P. Moser, M. E. Dollhopf et al., "Polyphasic taxonomy of the genus Shewanella and description of Shewanella oneidensis sp. nov," International Journal of Systematic Bacteriology, vol. 49, no. 2, pp. 705-724, 1999.

[52] J. F. Heidelberg, I. T. Paulsen, K. E. Nelson et al., "Genome sequence of the dissimilatory metal ion-reducing bacterium Shewanella oneidensis," Nature Biotechnology, vol. 20, no. 11, pp. 1118-1123, 2002.

[53] Y. J. Tang, A. L. Meadows, J. Kirby, and J. D. Keasling, "Anaerobic central metabolic pathways in Shewanella oneidensis MR-1 reinterpreted in the light of isotopic metabolite labeling," Journal of Bacteriology, vol. 189, no. 3, pp. 894-901, 2007.

[54] P. D. Martino, R. Fursy, L. Bret, B. Sundararaju, and R. S. Phillips, "Indole can act as an extracellular signal to regulate biofilm formation of Escherichia coli and other indole-producing bacteria," Canadian Journal of Microbiology, vol. 49, no. 7, pp. 443-449, 2003.

[55] J.-H. Lee and J. Lee, "Indole as an intercellular signal in microbial communities," FEMS Microbiology Reviews, vol. 34, no. 4, pp. 426-444, 2010. 
[56] M. Hu, C. Zhang, Y. Mu, Q. Shen, and Y. Feng, "Indole Affects biofilm formation in bacteria," Indian Journal of Microbiology, vol. 50, no. 4, pp. 362-368, 2010.

[57] T. H. Han, J.-H. Lee, M. H. Cho, T. K. Wood, and J. Lee, "Environmental factors affecting indole production in Escherichia coli," Research in Microbiology, vol. 162, no. 2, pp. 108-116, 2011.

[58] A. J. Varkey, M. D. Dlamini, A. B. Mansuetus, and A. T. Tiruneh, "Germicidal action of some metals/metal ions in combating E. coli bacteria in relation to their electrochemical properties," Journal of Water Resource and Protection, vol. 5, no. 12, pp. 1132-1143, 2013.

[59] D. J. Richardson, "Bacterial respiration: a flexible process for a changing environment," Microbiology, vol. 146, no. 3, pp. 551-571, 2000.

[60] T. J. DiChristina, C. M. Moore, and C. A. Haller, "Dissimilatory $\mathrm{Fe}(\mathrm{III})$ and $\mathrm{Mn}(\mathrm{IV})$ reduction by Shewanella putrefaciens requires ferE, a homolog of the pulE (gspE) type II protein secretion gene," Journal of Bacteriology, vol. 184, no. 1, pp. 142-151, 2002.

[61] H. H. Hau and J. A. Gralnick, "Ecology and biotechnology of the genus Shewanella," Annual Review of Microbiology, vol. 61, no. 1, pp. 237-258, 2007.

[62] J. Wen, S. Zhou, and J. Chen, "Colorimetric detection of Shewanella oneidensis based on immunomagnetic capture and bacterial intrinsic peroxidase activity," Scientific Reports, vol. 4, no. 1, 2014. 


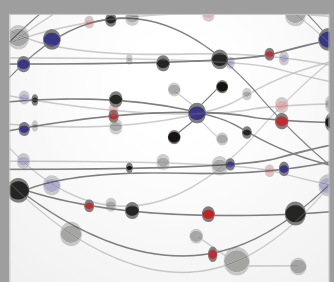

The Scientific World Journal
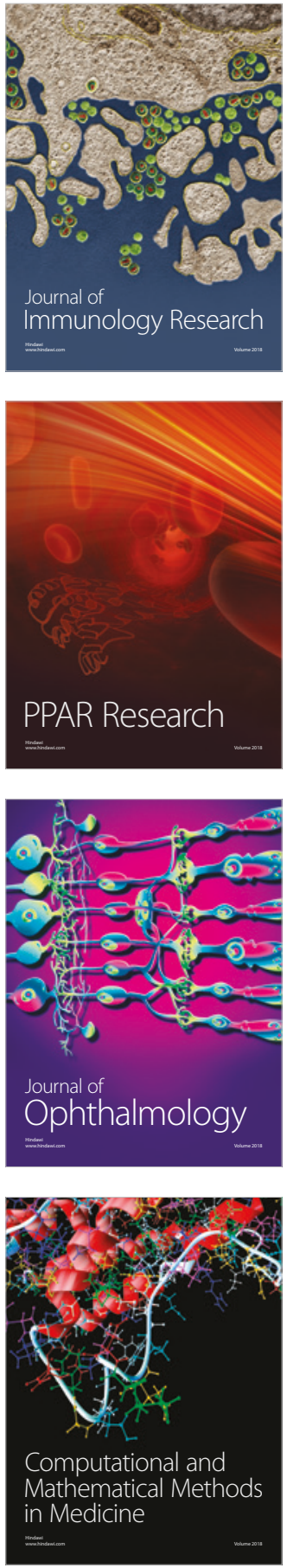

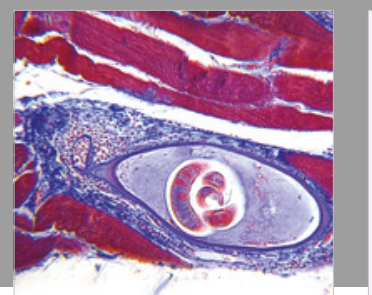

Gastroenterology Research and Practice

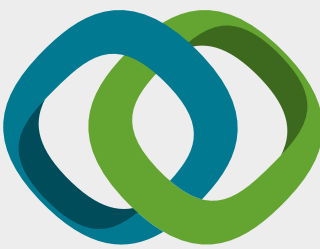

\section{Hindawi}

Submit your manuscripts at

www.hindawi.com
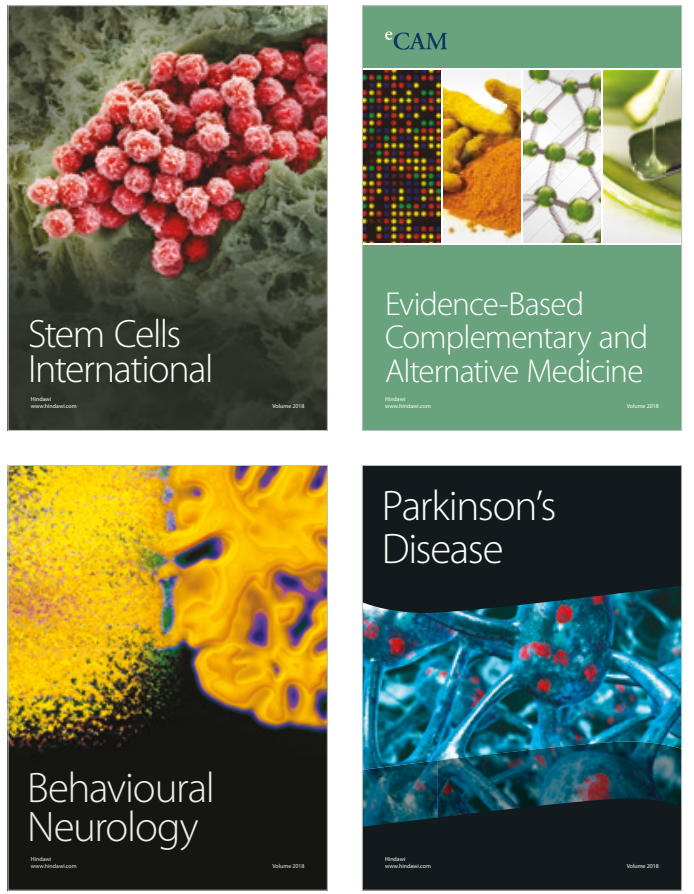

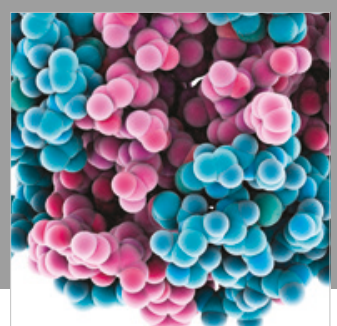

ournal of

Diabetes Research

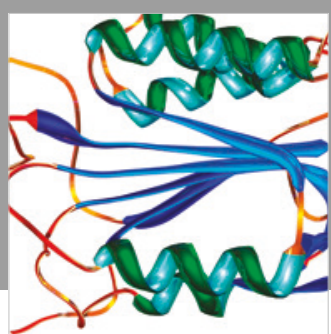

Disease Markers
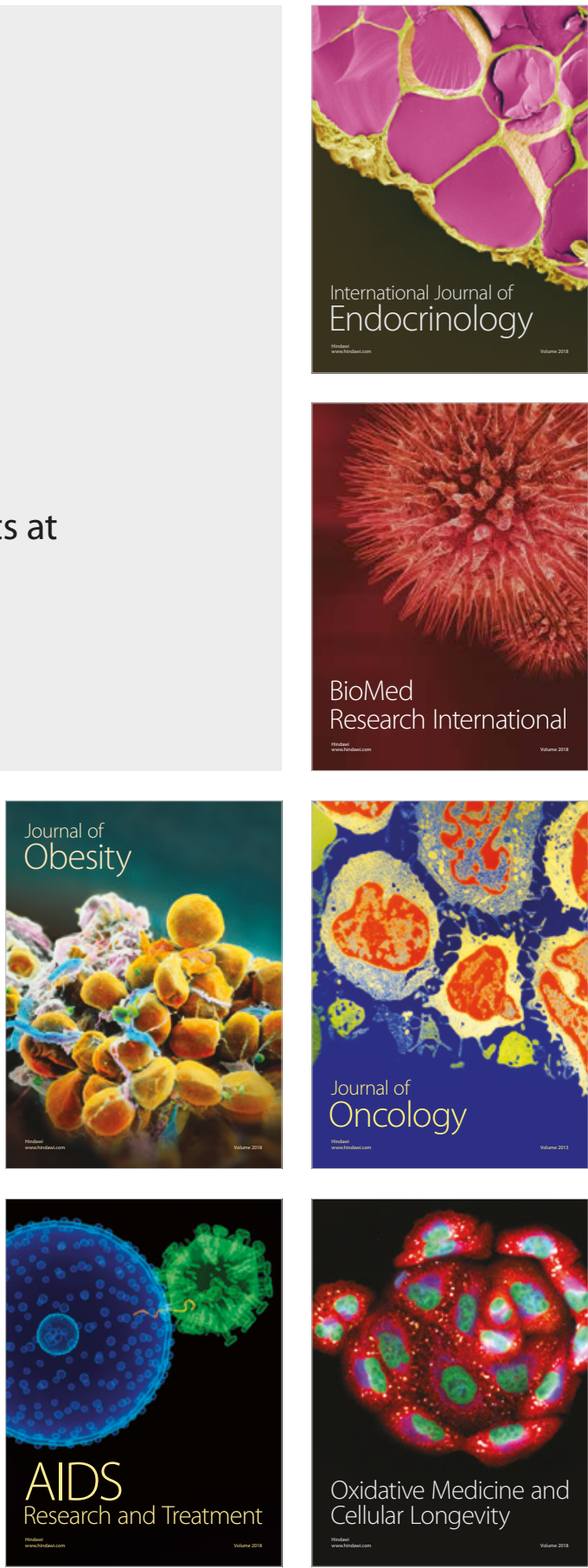